\title{
Diel Movements of Juvenile Illex illecebrosus and Other Cephalopods in the Shelf Water-Slope Water Frontal Zone off the Scotian Shelf in Spring
}

\author{
A. I. Arkhipkin and P. P. Fedulov \\ Atlantic Research Institute of Marine Fisheries and Oceanography (AtlantNIRO) \\ 5 Dmitry Donskoy Street, Kaliningrad, 236000, USSR
}

\begin{abstract}
Vertical water structure at two diel stations in the Shelf Water-Slope Water frontal zone seaward of the Scotian Shelf could be classified into five layers on the basis of some rather specific hydrographic characteristics. The near-surface layer $(0-30 \mathrm{~m})$ consisted of Shelf Water of low temperature and salinity, the second layer $(30-100 \mathrm{~m})$ represented the transition from Shelf Water to Slope Water, the third layer (100-200 m) consisted of Slope Water with maximum temperature and salinity, the fourth layer $(200-300 \mathrm{~m})$ extended from the lower boundary of Slope Water to the depth of minimum oxygen content, and the fifth layer (300-500 m) extended downward to the upper boundary of North Atlantic Central Water. Vertical distribution and diel migrations of juvenile Illex illecebrosus were closely associated with these layers and differed for the three modal size-groups $(3,5$ and $8 \mathrm{~cm}$ mantle length) of squid that were caught in a small-meshed midwater trawl. They preferred the second and fourth layers of increasing and decreasing temperatures respectively and tended to avoid the maximum temperatures of the third layer. The vertical distribution of other squid species, euphausiids and planktonic fishes seemed to be closely related to the hydrography of the defined layers.
\end{abstract}

\section{Introduction}

In recent years, there has been much interest in studying the biology of short-finned squid (IIlex illecebrosus) but little is known about the diel vertical movements of this cephalopod. Studies of this type of migration are important for obtaining reliable estimates of the abundance of larvae and juveniles in the Gulf Stream and Slope Water from winter-spring surveys prior to their immigration to the coastal shelves off the northeastern United States and eastern Canada where the fishery for them takes place during summer and autumn.

Short-finned squid larvae have been found mainly along the northern edge of the Gulf Stream and in the Gulf Stream-Slope Water frontal zone (Dawe and Beck, 1985; Hatanaka et al., 1985; Rowell et al., 1985). At night, they are dispersed in the 0-100 $\mathrm{m}$ water layer above the thermocline, but they move downward during the daytime and concentrate in depths of 50-100 m (Hatanaka et al., 1985). Juveniles with a size range of 11-29 mm ML (mantle length) were found to be abundant at about $100 \mathrm{~m}$ during the night but were caught in smaller numbers and at greater depths during the daytime (Fedulov and Froerman, MS 1980; Dawe et al., MS 1981). According to Hatanaka et al. (MS 1982) and Dawe et al. (MS 1982), larger juveniles (>30 mm ML) were usually found in Slope Water and were more abundant above the thermocline at stations where it was well pronounced. Fedulov and Froerman (MS 1980) supposed that their catches of juvenile I. illecebrosus were made above the layer of minimum oxygen content in Slope Water as deep as 150-300 m. In areas where the oxygen minimum was deeper (300-500 m). juveniles were caught in significant numbers in depths of $200-300 \mathrm{~m}$.

In an attempt to determine the features of the vertical distribution and diel movements of $I$. illecebrosus in the region of the Shelf Water-Slope Water frontal zone seaward of the Scotian Shelf, data were collected on a round-the-clock basis at two diel stations in the spring of 1983. Diel variability in vertical distribution of several size-groups of juvenile short-finned squid is related to variation in their feeding intensity as well as to diel movements of euphausiids and fish. The pattern of diel movements of $l$. illecebrosus is compared to those of other cepahlopods in the catches.

\section{Materials and Methods}

Data were collected at two diel stations during a survey of the research vessel Gizhiga in March-June 1983. Observations at the first station $\left(42^{\circ} 07^{\prime} \mathrm{N}\right.$, $63^{\circ} 36^{\prime} \mathrm{W}$ ) began at $2300 \mathrm{hr}$ on 27 April and ended at $1200 \mathrm{hr}$ on 30 April (Fig. 1A). Observations at the second station $\left(43^{\circ} 07^{\prime} \mathrm{N}, 57^{\circ} 59^{\prime} \mathrm{W}\right)$ were made from $0100 \mathrm{hr}$ to $2200 \mathrm{hr}$ on 24 May (Fig. 1B). The sea-surface temperature fields in Fig. 1 are from Canadian METOC (Meteorological and Oceanographic Centre) charts for the weeks in which the stations were occupied. At the start and end of each station, temperatures were measured and water samples for salinity and oxygen determinations were taken with Nansen bottles at standard depths from the surface to $1,000 \mathrm{~m}$. During the operations at both stations, temperature and oxygen were 

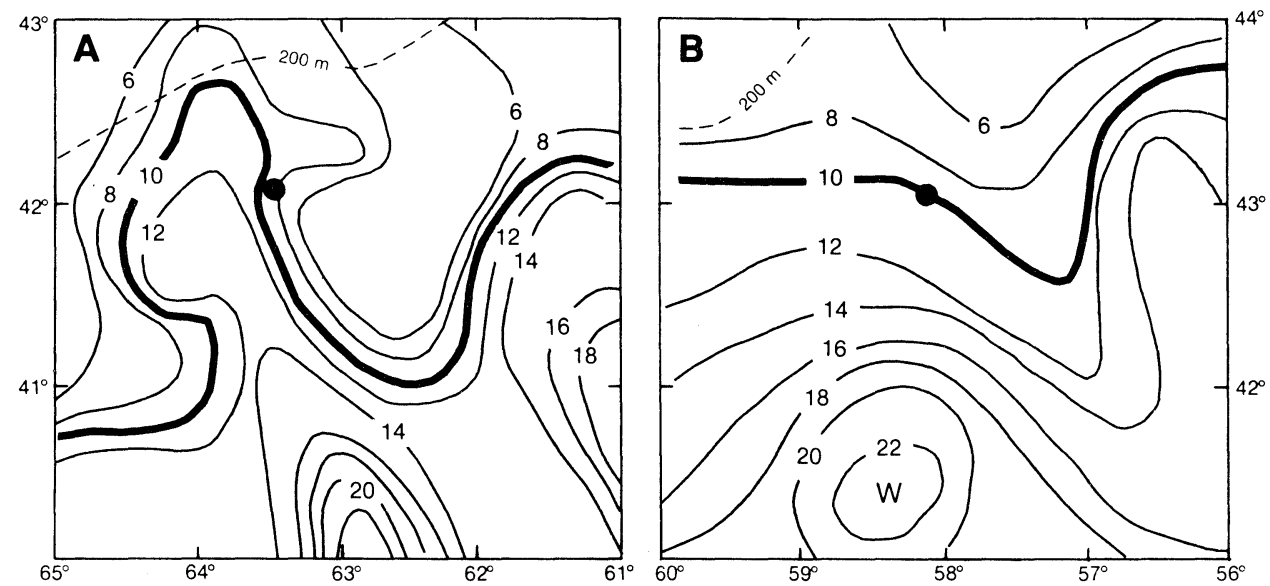

Fig. 1. Locations of diel stations in relation to the sea-surface temperature fields seaward of the Scotian Shelf in 1983: A, first diel station on 27-30 April; and B, second diel station on 24 May. (Surface temperatures from Canadian METOC charts for the week in which each station was occupied.)

monitored every $6 \mathrm{hr}$ by $\mathrm{TO}_{2} \mathrm{D}$-zond casts, which provided continuous vertical profiles of temperature and oxygen relative to depth. The temperature and salinity data, averaged at each depth for all Nansen bottle casts, were used to plot T-S curves to show the distribution of water masses at each station.

Midwater trawl sets were made at several depths from 35 to $500 \mathrm{~m}$ at the first diel station and from 25 to $300 \mathrm{~m}$ at the second one. The large trawl (66/336 type) with small-mesh liner ( $6 \mathrm{~mm}$ mesh size) was towed for $15 \mathrm{~min}$ at $3.5 \mathrm{knots}(6.5 \mathrm{~km} / \mathrm{hr})$. It was judged that very few animals were caught during retrieval of the trawl because it was pulled up vertically with its mouth opening virtually closed. It was assumed that squid were caught only by the small-mesh liner which had a mouth opening of $176 \mathrm{~m}^{2}$ (vertical opening was 7-8 m). For analysis, each trawl set was assigned to one of four periods of the 24-hour day: first half (1901-2400 hr) and second half (0001-0500 hr) of the dark period, and first half (0501-1200 hr) and second half (1201-1900 $\mathrm{hr}$ ) of the light period.

Each catch was sorted into planktonic fish, euphausiids and cephalopods, and each group was weighed. All cephalopods were identified to the level of genus and, where possible, to species by the key of Nesis (1982), after which they were counted and weighed. All I. illecebrosus were measured (dorsal mantle length, $\mathrm{mm} \mathrm{ML}$ ) when the catch was less than 100 specimens, and 100 were measured from larger catches. From these samples, 30 specimens were selected for biological analysis by the method outlined by Amaratunga and Durward (1979). To study the diel feeding behavior of squid, three categories of stomach fullness were used: (i) empty, (ii) food remnants present to about half full, and (iii) from half full to full.

An attempt was made to study the abundance of juvenile I. illecebrosus and other cephalopods and the biomass of fish and euphausiids by depth in relation to time of day at the first diel station. Only I. illecebrosus data were analyzed at the second diel station. Data from the day (0501-1900 hr) and night (1901-0500 hr) trawl sets were analyzed separately.

Temperature-salinity (T-S) curves were used to divide the water column at each diel station into layers which were observed to have some peculiar hydrographic features. To characterize the vertical distribution of animals within the water column, the abundance of cephalopods (number per $\mathrm{km}^{2}$ ) and biomass of fish and euphausiids ( $\mathrm{kg} \mathrm{per} \mathrm{km}^{2}$ ) were calculated for each of the layers. It was assumed that these values were constant for each layer during each of the two diel periods (1901-0500 hr and 0501-1900 hr). Because of the different thicknesses of the water layers, the absolute abundance of cephalopods during the day and night periods were estimated by averaging the catches at depths within a particular layer and extrapolating these values for the volume of the layer under a square kilometer $\left(1 \mathrm{~km}^{2}\right)$ at the position of each diel station. The absolute number of animals was considered to be more meaningful than catch per tow in comparing the abundance of animals in the different water layers.

\section{Results from First Diel Station}

\section{Hydrographic conditions}

The pattern of surface temperatures in the region around the first diel station (from Canadian METOC charts) indicated that it was located near the northern boundary of a well-defined northward meander of warm Slope Water (Fig. 1A). The mean thermal structure of the water column at this station was characterized by comparatively low temperatures (about $6^{\circ} \mathrm{C}$ ) at $30 \mathrm{~m}$ and maximum values in the 110-180 m layer (Fig. 2C). Mean salinity increased with depth from about 33.00 at the surface to maximum values $(35.10-35.20)$ at $150-200 \mathrm{~m}$ in the Slope Water. At greater depths, 

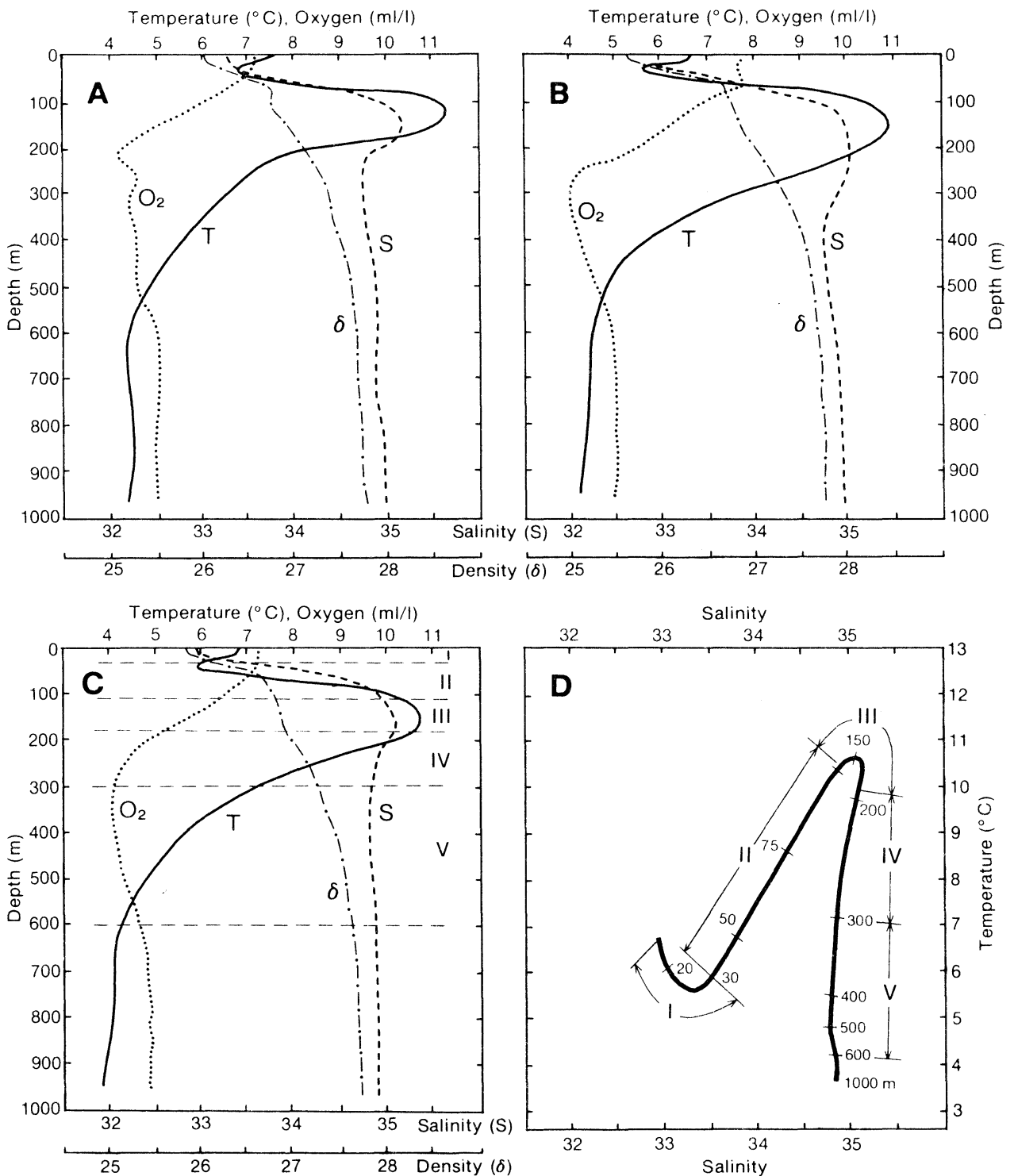

Fig. 2. Vertical distributions of temperature, salinity, oxygen and density at the first diel station: A, start of station; B, end of station; C, average for station period; D. T-S diagram with defined water masses at $0-30 \mathrm{~m}, 30-110 \mathrm{~m}, 110-180 \mathrm{~m}, 180-300 \mathrm{~m}$ and $300-600 \mathrm{~m}$.

salinity was almost constant (34.75-35.00). Although the vertical temperature and salinity structures in depths greater than about $30 \mathrm{~m}$ were essentially the same at the beginning and end of the station period (Fig. 2A, B), a noticeable decrease in temperature from $7.5^{\circ}$ to $6.0^{\circ} \mathrm{C}$ and in salinity from 33.35 to 32.60 occurred in the near-surface $(0-30 \mathrm{~m})$ layer. From supplementary temperature data during the fishing operations, this change occurred between 1500 and $1800 \mathrm{hr}$ on 29 April. The main feature of the oxygen distributions was the occurrence of minimum values $(4.0-4.3$ $\mathrm{ml} / \mathrm{l}$ ) at 200-300 $\mathrm{m}$.

From the temperature-depth profile (Fig. 2C) and the T-S curve (Fig. 2D), the water column at the first diel station was divided into layers which characterized some specific hydrographic features as follows:

a) Layer I (0-30 m) consisted of Shelf Water of low salinity (32.75-33.20) and low temperature $\left(6^{\circ}\right.$ to $\left.7^{\circ} \mathrm{C}\right)$.

b) Layer II (30-110 $\mathrm{m}$ ) represented the transition from Shelf Water to Slope Water, being characterized by increases in temperature $\left(6.0^{\circ}\right.$ to $\left.10.5^{\circ} \mathrm{C}\right)$ and salinity (33.20 to 34.90$)$ and maximum vertical gradients of these parameters.

c) Layer III (110-180 m) consisted of Slope Water with maximum temperature $\left(10.5^{\circ}\right.$ to $\left.11.0^{\circ} \mathrm{C}\right)$ and high salinity $(34.90-35.10)$.

d) Layer IV (180-300 $\mathrm{m}$ ) represented the zone from the lower warm Slope Water to the depth of minimum oxygen content, being characterized by a gradual 
decrease in temperature $\left(10.5^{\circ}\right.$ to $\left.7.0^{\circ} \mathrm{C}\right)$ and a slight decrease in salinity ( 35.10 to 34.90$)$. The depth of the oxygen minimum varied during the period of occupation of the diel station, and the mean depth of the minimum from all $\mathrm{TO}_{2} \mathrm{D}$-zond casts was taken as the lower boundary of this layer.

e) Layer V (300-600 $\mathrm{m})$ extended from the mean depth depth of minimum oxygen content to the North Atlantic Central Water, with no significant change in salinity and only a small decrease in temperature $\left(7^{\circ}\right.$ to $\left.6^{\circ} \mathrm{C}\right)$.

According to the trend in vertical density (Fig. 2C), the lower boundary of layer I was virtually the lower boundary of the seasonal pycnocline. The vertical gradient of density decreased noticeably in layer II and reached a local minimum in layer III. Division of the water column into layers by the vertical density structure was difficult, especially the deeper layers (III, IV and $V$ ), which were distinct by the vertical profiles of temperature, salinity and oxygen.

\section{Distribution of I. illecebrosus}

From 33 trawl sets at the first diel station, a total of 905 juvenile short-finned squid were caught (Table 1). The sex ratio was $1: 1$, and all squid were at maturity stage 1. The overall length range was $3.0-10.5 \mathrm{~cm} \mathrm{ML}$, and the length distributions exhibited modal sizegroups at $5 \mathrm{~cm}$ and $8 \mathrm{~cm}$.

The smallest short-finned squid $(5 \mathrm{~cm}$ modal group) were found mainly in layer II at depths of 35$100 \mathrm{~m}$ (Table 1). At night, the largest catches of this size-group (52-144 specimens per tow) were taken at $100 \mathrm{~m}$ and somewhat smaller catches (20-22 per tow) occurred at $50 \mathrm{~m}$, with only a few specimens from greater depths (layers III, IV and V). During daylight, these small squid were much less abundant than at night, except for a large catch (234 specimens) at twilight on 29 April. This unusual catch at $35 \mathrm{~m}$ occurred at the time when sharp decreases in temperature and salinity were noticed in the upper $35 \mathrm{~m}$. This change in hydrographic conditions may have caused the aggregation of small squid just below layer I. Catches in earlier tows at 35 and $50 \mathrm{~m}$ contained only $0-3$ specimens.

The larger short-finned squid ( $8 \mathrm{~cm}$ modal group) were concentrated mainly in layer IV, where the largest catches at $200 \mathrm{~m}$ were approximately the same (41 and 43 specimens) in day and night tows. However, the largest catch at $300 \mathrm{~m}$ (109 specimens) occurred during a daytime tow. At night, small numbers of this size-group apparently moved upward to layer II, as indicated by the catches ( $8-11$ specimens) at $50-100$ $\mathrm{m}$. No short-finned squid were caught at $500 \mathrm{~m}$, and, interestingly, very few were caught in the layer of maximum temperature (layer III). The length distributions of day and night catches reflect the aggregation of small squid at 35-100 $\mathrm{m}$ in layer II (Fig. 3A, B) and larger squid at 200-300 $\mathrm{m}$ in layer IV (Fig. 3C, D).

Observations on the feeding behavior of juvenile 1 . illecebrosus indicated that $80 \%$ or more of the smallest animals ( $5 \mathrm{~cm}$ modal group) had empty stomachs during the afternoon and night periods (Fig. 4A), but there was a substantial increase in the proportion with food

TABLE 1. Numbers of juvenile I. illecebrosus in catches at the first diel station (27-30 April 1983) by depth, time interval and modal size-group. (Night catches in bold type; number of trawl tows in parentheses.)

\begin{tabular}{|c|c|c|c|c|c|c|c|c|c|c|c|c|c|c|c|}
\hline \multirow{3}{*}{$\begin{array}{l}\text { Depth } \\
\text { Layer }\end{array}$} & \multirow{3}{*}{$\begin{array}{l}\text { Depth } \\
\text { of set } \\
(\mathrm{m})\end{array}$} & \multirow{3}{*}{$\begin{array}{l}\text { Modal } \\
\text { group } \\
(\mathrm{cm})\end{array}$} & \multirow{3}{*}{$\begin{array}{l}\frac{27 \mathrm{Apr}}{1901} \\
2400\end{array}$} & \multicolumn{4}{|c|}{$28 \mathrm{Apr}$} & \multicolumn{4}{|c|}{$29 \mathrm{Apr}$} & \multicolumn{2}{|c|}{$30 \mathrm{Apr}$} & \multirow{2}{*}{\multicolumn{2}{|c|}{$\begin{array}{l}\text { Average number } \\
\text { per set }\end{array}$}} \\
\hline & & & & $\overline{0001}$ & 0501 & 1201 & $\overline{1901}$ & $\overline{0001}$ & 0501 & 1201 & $\overline{1901}$ & 0001 & 0501 & & \\
\hline & & & & 0500 & 1200 & 1900 & 2400 & 0500 & 1200 & 1900 & 2400 & 0500 & 1200 & Day & Night \\
\hline \multirow[t]{6}{*}{11} & 35 & 5 & 9 & - & 0 & - & - & 0 & - & 234 & - & 0 & - & 117.0 & 3.0 \\
\hline & & 8 & 3 & - & 0 & - & - & 0 & - & 0 & - & 6 & - & $0.0^{(2)}$ & $3.0^{(3)}$ \\
\hline & 50 & 5 & - & 22 & 3 & - & 5 & - & - & 2 & - & 20 & - & 2.5 & 15.7 \\
\hline & & 8 & - & 3 & 0 & - & 6 & - & - & 1 & - & 8 & - & $0.5^{(2)}$ & $5.7^{(3)}$ \\
\hline & 100 & 5 & 52 & - & 0 & 0 & 96 & - & 1 & - & 144 & - & - & 0.3 & 97.0 \\
\hline & & 8 & 1 & - & 0 & 0 & 9 & - & 3 & - & 11 & - & - & $1.0^{(3)}$ & $7.0^{(3)}$ \\
\hline \multirow{2}{*}{ III } & 150 & 5 & - & - & 0 & - & 6 & - & 1 & - & - & - & 0 & 0.3 & 6.0 \\
\hline & & 8 & - & - & 0 & - & 0 & - & 1 & - & - & - & 0 & $0.3^{(3)}$ & $0.0^{(1)}$ \\
\hline \multirow[t]{4}{*}{ IV } & 200 & 5 & - & - & - & 3 & - & 5 & 2 & - & - & 3 & - & 2.5 & 4.0 \\
\hline & & 8 & - & - & - & 41 & - & 43 & 3 & - & - & 3 & - & $22.0^{(2)}$ & $23.0^{(2)}$ \\
\hline & 300 & .5 & - & 9 & 0 & - & 6 & - & - & 12 & - & 1 & - & 6.0 & $5.3(3)$ \\
\hline & & 8 & - & 5 & 3 & - & 0 & - & - & 109 & - & 10 & - & $56.0^{(2)}$ & $5.0^{(3)}$ \\
\hline \multirow[t]{3}{*}{ V } & 500 & 5 & - & - & - & 0 & - & 0 & - & 0 & 0 & - & - & 0.0 & 0.0 \\
\hline & & 8 & - & - & - & 0 & - & 0 & - & 0 & 0 & - & - & $0.0^{(2)}$ & $0.0^{(2)}$ \\
\hline & Totals & & 65 & 39 & 6 & 44 & 128 & 48 & 11 & 358 & 155 & 51 & 0 & 419 (16) & $486(17)$ \\
\hline
\end{tabular}




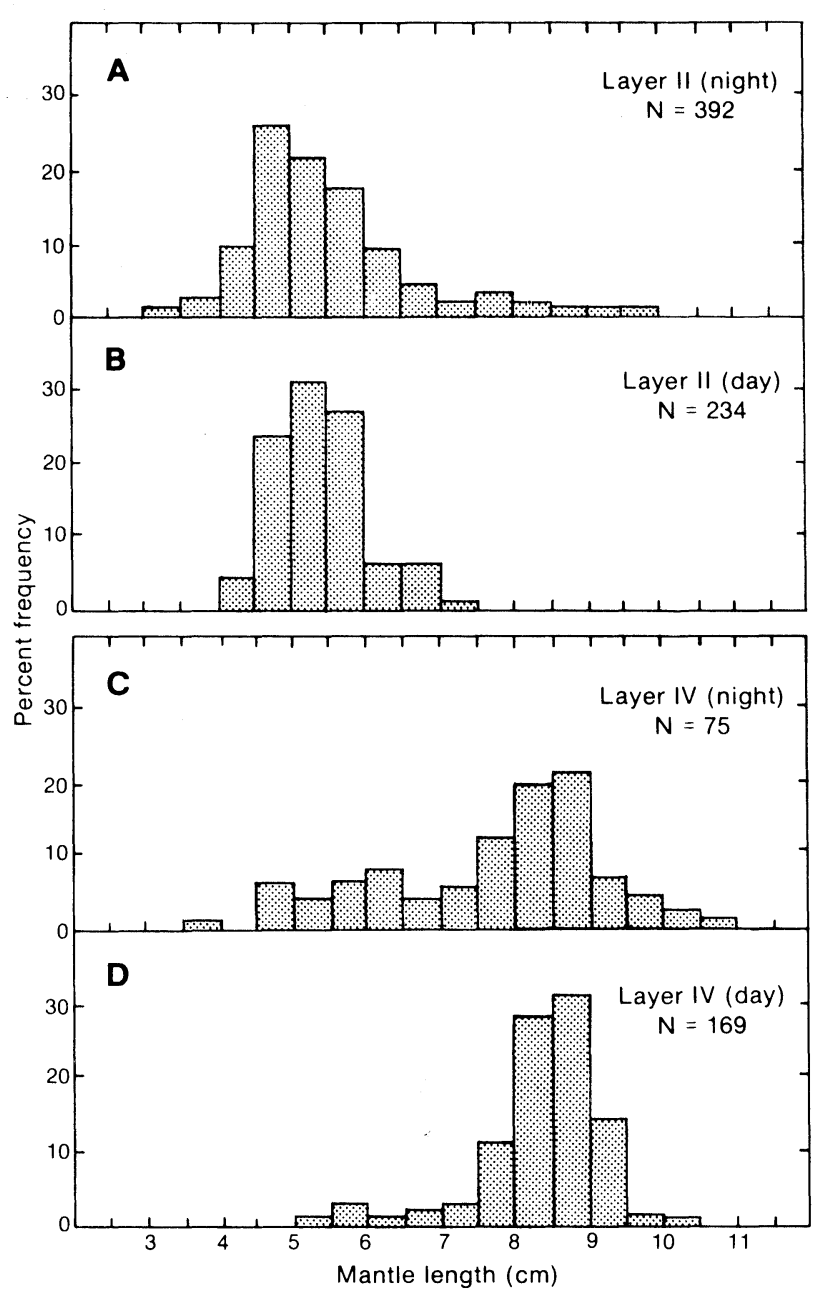

Fig. 3. Length distributions of juvenile I. illecebrosus in day and night catches from layers II and IV at the first diel station.

during the morning period. For the $8 \mathrm{~cm}$ modal group (Fig. 4B), the highest proportion with empty stomachs was observed in the night catches, and the highest proportion with full stomachs occurred during the morning period. The larger juveniles had higher proportions of stomachs with food than the smaller ones.

\section{Distribution of other cephalopods}

Apart from I. illecebrosus, a total of 678 cephalopods belonging to 20 species of 12 families were caught in the trawl sets at the first diel station (Table 2). Of these species, Arctic squid (Gonatus fabricii) were the most abundant (406 specimens), their mean weight being $1.7 \mathrm{~g}$. These squid were concentrated mainly in layer $\mathrm{V}(300-600 \mathrm{~m})$ and possibly deeper during the daytime, but many moved closer to the surface into layers II, III and IV at night. The next most numerous species in the catches were Onychoteuthis banksi (41 specimens), Pyroteuthis margaritifera (38) and Leachia sp. (37), which occurred in the deeper layers during the daytime and moved to shallower layers at night,

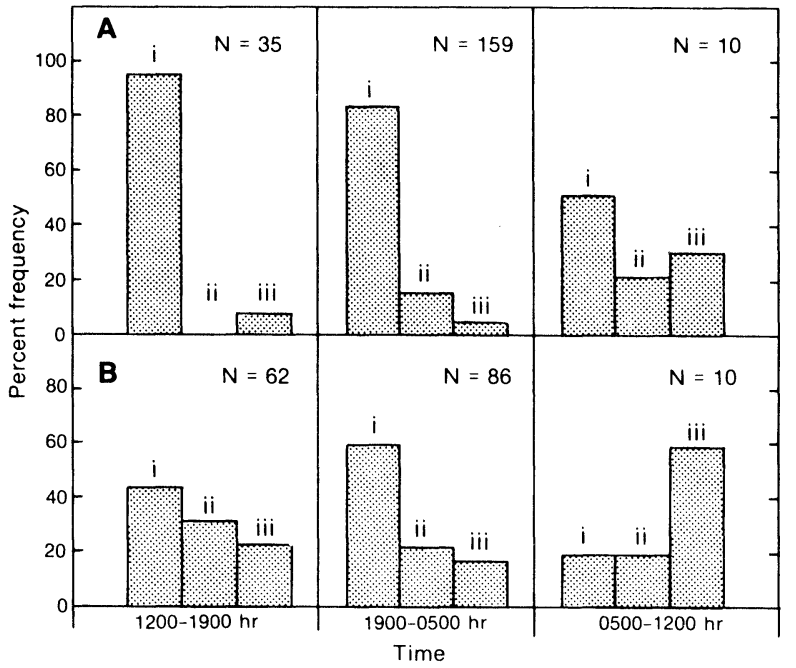

Fig. 4. Diel feeding behavior of $5 \mathrm{~cm}$ (upper) and $8 \mathrm{~cm}$ (lower) modal size-groups of 1 . illecebrosus at the first diel station, as indicated by gut fullness indices for empty (i), up to half-full (ii) and half-full to full (iii)

and Abraliopsis hoylei (37), which exhibited a reverse movement from layers II and III during daytime to layer IV at night. An interesting feature of the occurrence of cephalopods in Table 2 is that, during both day and night periods, more species were recorded in the catches from layers II, IV and V (above and below the levels of maximum temperature) than from layer III (level of maximum temperature).

\section{Distribution of euphausiids and fish}

Euphausiids were found mostly at night $(82 \%)$ in all water layers (Table 3 ), with maximum abundance in layer II. During the daytime, euphausiids were taken mainly in layer $\mathrm{V}$, and, from the absolute values of biomass in all layers during day and night periods, it is likely that the major concentrations were located below the maximum depth of sampling $(500 \mathrm{~m})$ during the daytime. The mean weight of euphausiids from the different depth zones were quite similar $(0.3-0.4 \mathrm{~g})$. The vertical distribution of euphausiids was similar to that of Gonatus fabricii in that they were abundant at night in all layers and were most abundant in layer $V$ during the daytime. Euphausiids were least abundant in the zone of maximum temperature (layer III) where the diversity and abundance of cephalopods were lowest.

A significant portion of the fish that were caught at shallow depths (up to $70-80 \%$ by weight) were myctophids. These fish were very abundant in layer $V$ during the daytime (32 tons $/ \mathrm{km}^{2}$ ) (Table 3), but they moved up to layers II, III and IV at night, with maximum biomass in layer III (20.4 tons $\left./ \mathrm{km}^{2}\right)$. Up to $30-40 \%$ of the deepwater (layer V) catches consisted of various bathypelagic and mesopelagic fishes. 
TABLE 2. Total numbers caught and estimated numbers (specimens per $\mathrm{km}^{2}$ ) of various cephalopods in four water layers at the first diel station (27-30 April 1983) during the day and night periods.

\begin{tabular}{|c|c|c|c|c|c|c|c|c|c|c|}
\hline \multirow[b]{3}{*}{ Family/Species } & \multicolumn{5}{|c|}{ Daylight $(0501-1900 \mathrm{hr})$} & \multicolumn{5}{|c|}{ Darkness (1901-0500 hr) } \\
\hline & \multirow{2}{*}{$\begin{array}{c}\text { Number } \\
\text { caught }\end{array}$} & \multicolumn{4}{|c|}{ Estimated number by layer } & \multirow{2}{*}{$\begin{array}{c}\text { Number } \\
\text { caught }\end{array}$} & \multicolumn{4}{|c|}{ Estimated number by layer } \\
\hline & & 11 & 111 & IV & $\overline{\mathrm{V}}$ & & 11 & III & IV & V \\
\hline \multicolumn{11}{|l|}{ Family Ommastrephidae } \\
\hline Illex illecebrosus & 185 & 302 & 97 & 15,375 & - & 486 & 10,293 & 1,237 & 6,405 & - \\
\hline Ornithoteuthis antillarum & 1 & - & - & 71 & - & 0 & - & - & - & - \\
\hline \multicolumn{11}{|l|}{ Family Alloposidae } \\
\hline Alloposus mollis & 3 & - & - & 71 & 883 & 9 & 71 & - & 353 & 441 \\
\hline \multicolumn{11}{|l|}{ Family Brachioteuthidae } \\
\hline Brachioteuthis risii & 1 & - & - & 71 & - & 7 & 141 & - & 106 & 441 \\
\hline \multicolumn{11}{|l|}{ Family Chiroteuthidae } \\
\hline Chiroteuthis veranyi & 0 & - & - & - & - & 7 & - & - & 141 & 2,208 \\
\hline \multicolumn{11}{|l|}{ Family Cranchiidae } \\
\hline Cranchia scabra & 1 & - & - & 71 & - & 0 & - & - & - & - \\
\hline Galiteuthis armata & 1 & - & - & - & 441 & 2 & - & - & - & 883 \\
\hline Helicocranchia pfefferi & 6 & - & - & 353 & - & 0 & - & - & - & - \\
\hline Leachia sp. & 11 & 33 & - & 176 & 3,534 & 26 & 304 & 1,835 & 282 & 441 \\
\hline Teuthowenia megalops & 1 & - & - & 71 & - & 9 & 163 & - & 71 & 883 \\
\hline \multicolumn{11}{|l|}{ Family Ctenopterygidae } \\
\hline Ctenopteryx sicula & 0 & - & - & - & - & 2 & - & 40 & - & - \\
\hline \multicolumn{11}{|l|}{ Family Enoploteuthidae } \\
\hline Abralia sp. & 8 & 70 & - & 424 & - & 4 & 71 & - & 106 & - \\
\hline Abraliopsis hoylei & 15 & 303 & 309 & 177 & - & 16 & 93 & - & 954 & - \\
\hline Pterygioteuthis gemmata & 11 & 93 & - & 706 & - & 9 & 212 & - & 71 & - \\
\hline Pyroteuthis margaritifera & 11 & 155 & - & 530 & - & 27 & 375 & 618 & 707 & - \\
\hline \multicolumn{11}{|l|}{ Family Gonatidae } \\
\hline Gonatus fabricii & 62 & 706 & 203 & 619 & 14,137 & 344 & 1,678 & 7,377 & 15,020 & 13,253 \\
\hline \multicolumn{11}{|l|}{ Family Histioteuthidae } \\
\hline Histioteuthis bonnellii & 2 & - & - & - & 883 & 8 & - & - & 530 & 883 \\
\hline \multicolumn{11}{|l|}{ Family Mastigoteuthidae } \\
\hline Mastigoteuthis sp. & 0 & - & - & - & - & 21 & - & - & 1,413 & 2,208 \\
\hline \multicolumn{11}{|l|}{ Family Octopoteuthidae } \\
\hline Octopoteuthis sp. & 4 & - & - & 176 & 883 & 7 & - & 41 & 141 & 1,324 \\
\hline \multicolumn{11}{|l|}{ Family Onychoteuthidae } \\
\hline Ancistroteuthis lichtensteini & 1 & - & - & 71 & - & 0 & - & - & - & - \\
\hline Onychoteuthis banksi & 2 & 33 & - & - & 441 & 39 & 963 & - & 141 & - \\
\hline Total Illex illecebrosus & 185 & 302 & 97 & 15,375 & - & 486 & 10,293 & 1,237 & 6,405 & - \\
\hline Total other cephalopods & 141 & 1,393 & 512 & 3,587 & 21,202 & 537 & 4,071 & 9,911 & 20,036 & 22,965 \\
\hline Number of species & 18 & 8 & 3 & 15 & 7 & 17 & 11 & 6 & 15 & 10 \\
\hline
\end{tabular}

TABLE 3. Day and night catches of euphausiids and fish and estimated biomass by water layer at the first diel station (27-30 April 1983).

\begin{tabular}{llrrrrr}
\hline \hline $\begin{array}{c}\text { Animal } \\
\text { group }\end{array}$ & Period & $\begin{array}{c}\text { Catch } \\
(\mathrm{kg})\end{array}$ & \multicolumn{5}{c}{ Estimated biomass $\left(\mathrm{kg} / \mathrm{km}^{2}\right)$} \\
\cline { 5 - 8 } Euphausiids & Day & 9 & 35 & 9 & 1,222 & 4,417 \\
& Night & 76 & 9,368 & 2,606 & 5,274 & 7,676 \\
\multirow{3}{*}{ Fishes } & & & & & & \\
& Day & 48 & 93 & 62 & 3,931 & 31,986 \\
& Night & 184 & 6,650 & 20,410 & 11,897 & 20,109 \\
\hline
\end{tabular}

\section{Results from Second Diel Station}

\section{Hydrographic conditions}

The second diel station on 24 May 1983 was located about $450 \mathrm{~km}$ eastward and slightly north of the first diel station (Fig. 1B). Vertical structure of the water column remained virtually the same throughout the sampling period (Fig. 5) and was generally similar to that nearly a month earlier at the first diel station (Fig. 2). Major differences were as follows: the level of minimum oxygen at $250 \mathrm{~m}$ was much shallower than at the first station; the temperature at the surface $\left(10.6^{\circ} \mathrm{C}\right)$ and the minimum at $30 \mathrm{~m}\left(8.2^{\circ} \mathrm{C}\right)$ were higher than those at the first station; and the 100-200 m layer, with temperature range of $11.0^{\circ}$ to $12.8^{\circ} \mathrm{C}$ and salinity range of $35.00-35.60$, was clearly defined with maximum values at about $150 \mathrm{~m}$. Thus, there was a stronger presence of Slope Water at the second diel station than at the first.

From the temperature-depth profile and the T-S curve for the second station (Fig. 5), the water column 

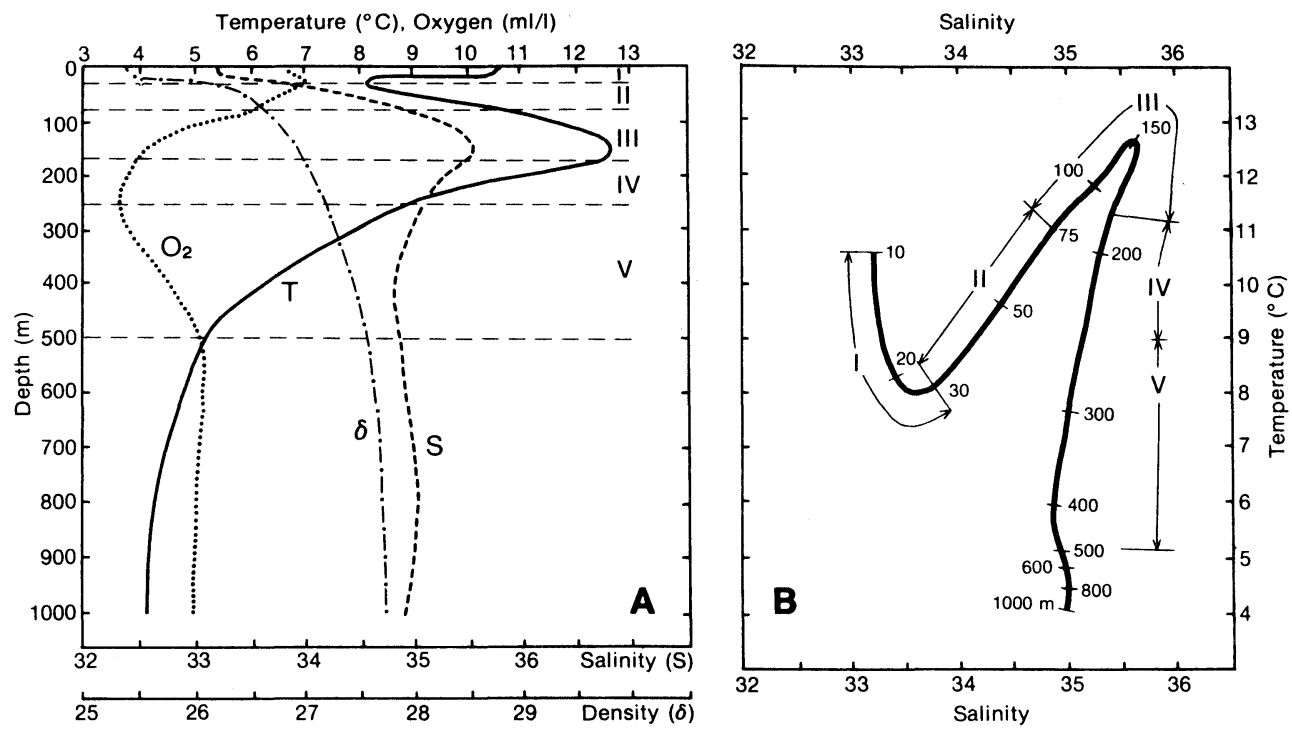

Fig. 5. Vertical distribution of temperature, salinity, oxygen and density at the second diel station: A, average for station period; B, T-S diagram with defined water layers at 0-30 m, 30-75 m, 75-180 m, 180-250 m and $250-500 \mathrm{~m}$.

was divided into layers, similar to those for the first station, as follows:

a) Layer I $(0-30 \mathrm{~m})$ consisted of Shelf Water of low salinity (33.25-33.75) and moderately low temperature $\left(8.0^{\circ}\right.$ to $\left.10.5^{\circ} \mathrm{C}\right)$.

b) Layer II (30-75 m) was intermediate between Shelf Water and Slope Water with increasing temperature $\left(8.0^{\circ}\right.$ to $\left.11.0^{\circ} \mathrm{C}\right)$ and salinity $(33.75$ to 34.85$)$.

c) Layer III (75-180 m) consisted of Slope Water with maximum temperature $\left(10.5^{\circ}\right.$ to $\left.12.7^{\circ} \mathrm{C}\right)$ and salinity (34.85-35.60).

d) Layer IV (180-250 m), which extended from the lower boundary of Slope Water to the depth of the oxygen minimum, was characterized by decreases in temperature $\left(10.5^{\circ}\right.$ to $\left.9.0^{\circ} \mathrm{C}\right)$ and salinity (35.40-35.20). The oxygen content continued to decline (Fig. 5A) and reached the minimum (3.8 $\mathrm{ml} / \mathrm{I})$ at about $250 \mathrm{~m}$.

e) Layer V (250-500 m) extended from the depth of minimum oxygen to the upper boundary of North Atlantic Central Water, with decreasing temperature $\left(9.0^{\circ}\right.$ to $\left.5.0^{\circ} \mathrm{C}\right)$ and small variation in salinity (34.85-35.25).

\section{Distribution of I. illecebrosus}

Only the short-finned squid data from the second diel station were analysed. Squid were taken in 7 of 14 trawl tows (Table 4), but most of the specimens were taken in three tows at 40 and $60 \mathrm{~m}$ in layer II, where day and night catches yielded 1,382 and 219 squid respectively. Very few specimens were taken at $100 \mathrm{~m}$ (layer III) and none in tows at greater depths.
The overall length range of sampled specimens was $2.0-6.5 \mathrm{~cm} \mathrm{ML}$, and the length distributions of the day and night catches were unimodal with the mode at $3 \mathrm{~cm}$ (Fig. 6). The sex ratio was approximately 1:1, and all specimens were at maturity stage I. Information on diel feeding was not possible because all specimens had empty stomachs.

\section{Discussion}

\section{Short-finned squid}

The results from the diel stations indicated differences in the vertical distribution of juveniles of the 3,5 and $8 \mathrm{~cm} \mathrm{ML} \mathrm{modal} \mathrm{size-groups} \mathrm{in} \mathrm{the} \mathrm{region} \mathrm{of} \mathrm{the}$ Shelf Water-Slope Water frontal zone seaward of the Scotian Shelf.

Juveniles of $\mathbf{3} \mathbf{~ c m ~ m o d a l ~ g r o u p . ~ T h e s e ~ s q u i d ~ w e r e ~}$ caught only at the second diel station. They were concentrated in layer II where the hydrographic conditions were representative of the Shelf Water-Slope Water transitional zone. Their capture in both day and night tows at 40 and $60 \mathrm{~m}$ and their scarcity at greater depths imply that they do not undertake larger vertical movements and are not mobile enough to escape the trawl during the daytime tows. In this transitional zone (layer II), there are plenty of planktonic organisms (Voronina, 1984) on which these young squid probably feed during both day and night. Since the metabolic rate of small animals is usually quite high, it is not surprising that the guts of these small squid were empty. It is unlikely that small squid are affected greatly by predatory stress in layer II, because only a small proportion 
TABLE 4. Numbers of juvenile I. illecebrosus in catches at the second diel station (24 May 1983) by depth, time interval and modal size group. (Night sets in bold type; number of trawl tows in parentheses.)

\begin{tabular}{|c|c|c|c|c|c|c|c|c|}
\hline \multirow{3}{*}{$\begin{array}{l}\text { Depth } \\
\text { layer }\end{array}$} & \multirow{3}{*}{$\begin{array}{l}\text { Depth } \\
(\mathrm{m})\end{array}$} & \multirow{3}{*}{$\begin{array}{l}\text { Modal } \\
\text { group } \\
(\mathrm{cm})\end{array}$} & \multicolumn{4}{|c|}{24 May } & \multirow{2}{*}{\multicolumn{2}{|c|}{$\begin{array}{c}\text { Average number } \\
\text { per set }\end{array}$}} \\
\hline & & & 0001 & 0501 & 1201 & $\overline{1901}$ & & \\
\hline & & & 0500 & 1200 & 1900 & 2400 & Day & Night \\
\hline \multirow[t]{2}{*}{1} & 25 & 3 & - & - & - & 0 & - & $0_{\text {(1) }}$ \\
\hline & & 5 & - & - & - & 0 & - & $0^{(1)}$ \\
\hline \multirow{4}{*}{ II } & 40 & 3 & 216 & 250 & - & - & 250 & 216 \\
\hline & & 5 & 0 & 0 & - & - & $0^{(1)}$ & $0^{(1)}$ \\
\hline & 60 & 3 & 1 & 4 & 1,127 & - & 1,131 & 1 \\
\hline & & 5 & 2 & 0 & 1 & - & $1^{(2)}$ & $2^{(1)}$ \\
\hline \multirow{4}{*}{ III } & 100 & 3 & 7 & 0 & 2 & - & 2 (2) & 7 (1) \\
\hline & & 5 & 4 & 0 & 0 & - & $0^{(2)}$ & $4^{(1)}$ \\
\hline & 150 & 3 & - & 0 & - & - & $0_{(1)}$ & - \\
\hline & & 5 & - & 0 & - & - & 0 & - \\
\hline & 200 & 3 & 0 & 0 & - & 0 & $0_{\text {(1) }}$ & $0_{\text {(2) }}$ \\
\hline IV & & 5 & 0 & 0 & - & 0 & $0^{(1)}$ & $0^{(2)}$ \\
\hline \multirow[t]{3}{*}{ V } & 300 & 3 & - & - & 0 & - & 0 & - \\
\hline & & 5 & - & - & 0 & - & $0^{(1)}$ & - \\
\hline & Totals & & 230 & 254 & 1,130 & 0 & $1,384(8)$ & $230(6)$ \\
\hline
\end{tabular}

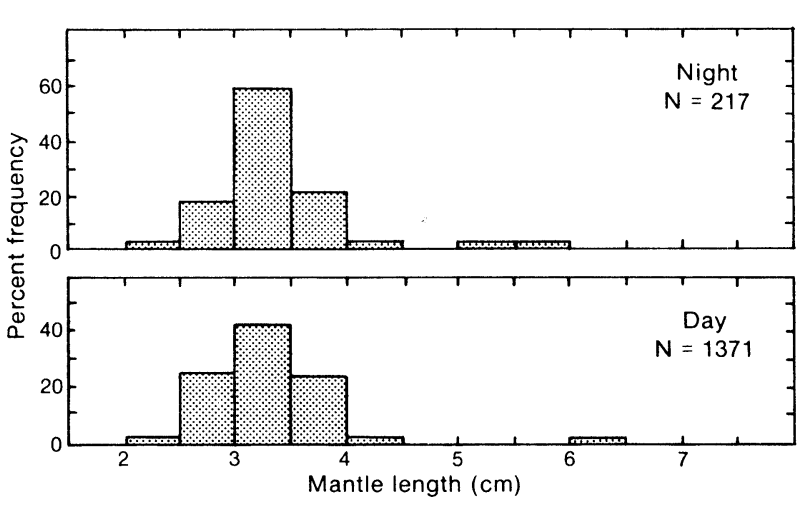

Fig. 6. Length distributions of juvenile I. illecebrosis in day and night catches from layer II at the second diel station.

of potential predators (mesopelagic and bathypelagic fishes) migrate upward into this layer at night. Therefore, conditions seem to be favorable for young squid of this modal group to remain in layer II during both day and night.

Juveniles of $5 \mathrm{~cm}$ modal group. These squid, which were dominant at the first diel station, were abundant in some catches from layer II at night. During the daytime, catches were usually not large (3-4 specimens per tow) and were mainly from layer IV. It is possible that the major portion of these squid remained in layer II during both day and night and that only small numbers moved to layer IV. Squid of this size-group are active nektonic animals and depend mainly on eyesight when moving through the water. The stomach contents of juveniles (Froerman et al., MS 1981) imply that squid as small as $4 \mathrm{~cm} \mathrm{ML}$ are capable of signifi- cant movement. These squid may easily escape from the trawl during the day when illumination in layer II is good, whereas they are caught in larger numbers during the night when illumination is poor.

Data on diel feeding behavior can serve as an indirect indication that these small squid remain mainly in layer II during both day and night. Guts from squid of this size-group at night and at dawn contained mainly the remnants of euphausiids (easily identified by their red color) which were abundant in layer 11 at these times. In the daytime, when euphausiids moved to greater depths, nearly all of the squid stomachs were empty. If squid of this size-group had moved to layers IV and $V$ in greater numbers in the daytime, they would have been caught in larger numbers there and they would have been feeding throughout the day, as observed for the $8 \mathrm{~mm}$ modal group. It is supposed, therefore, that the $5 \mathrm{~cm}$ squid stayed mainly in layer II during the daytime.

Juveniles of $8 \mathrm{~cm}$ modal group. The majority of squid of this size-group were caught only at the first diel station in the zone of sharp temperature gradient below the Slope Water but above the level of minimum oxygen (layer IV), and none were found at greater depths. Because the illumination at $200-300 \mathrm{~m}$ was much lower than at shallower depths, these squid did not escape from the trawl and were caught in larger numbers during the day relative to the $5 \mathrm{~cm}$ juveniles, which were found mainly in layer II where illumination is much better than in layer IV.

Both euphausiids and small fish were plentiful in layer IV during the day and night periods (Table 3 ). The 
proportions of squid with full guts during the second half of the light period (1201-1900 hr) and during darkness (1901-0500 hr) were approximately equal (about $20 \%$ ), but there was a sharp increase in the proportion with full guts in the morning $(60 \%)$. During this period (0501-1900 hr), the squid evidently fed intensively on euphausiids and fish which were moving downward into the mesopelagic zone (layer $\mathrm{V}$ and deeper) as illumination in the upper layers increased.

\section{Other cephalopods}

Almost all of the squid species in the catches (except I. illecebrosus and G. fabricii) are planktonic and micronektonic animals (Nesis, 1982), which are not capable of avoiding or escaping from the trawl. Since the numbers of day and night tows were approximately equal (Table 1), it was supposed that a species was absent or very scarce in a layer if none were caught there in a particular time period. Most of the bathypelagic and mesopelagic squid species were caught in layers IV and $V$ at night and were virtually absent in all layers during the daytime (Table 2). Thus, these species were believed to be deeper than $500 \mathrm{~m}$ in the daytime although there were no trawl tows to confirm this view. Despite the small catches of most of these cephalopods, it was considered possible to classify them into three types according to their patterns of vertical distribution.

The first type (A) includes mainly squids of the family Enoploteuthidae which inhabit layers II to IV. Abralia sp., Pterygioteuthis gemmata and Pyroteuthis margaritifera were located mainly in layer IV during the day and in layer II at night. However, the diel movements of Abraliopsis hoylei were opposite to those of the other three species, in that they were found mainly in layers II and III during the day and in layer IV at night. Roper and Young (1975) observed the same pattern of vertical movement for Abraliopsis pfefferi. Although no species of enoploteuthids were found deeper than 200-300 $\mathrm{m}$ (layer IV), they have been reported to range as deep as 1,000-1,200 $\mathrm{m}$ (Roper and Young 1975: Nesis, 1977). The pattern of vertical movements of $I$. illecebrosus $(3-10 \mathrm{~cm} \mathrm{ML})$ was similar in general to that of the enoploteuthids and it belongs to type $A$.

The second type (B) represents the squids which inhabit zones deeper than $500 \mathrm{~m}$ in the daytime and move up at night to the level of oxygen minimum and increasing temperature (layer IV). These species include Chiroteuthis veranyi, Galiteuthis armata, Histioteuthis bonnellii and Mastigoteuthis sp.

The third type (C) represents a group of squids which are closely related to the second group. These are found deeper than $500 \mathrm{~m}$ in the daytime and move up to the level of maximum temperature (layer III) and even shallower (layer II) at night. These species include Alloposus mollis, Brachioteuthis rissii, Ctenopteryx sicula, Onychoteuthis banksi and Teuthowenia megalops (to layer II), and Octopoteuthis sp. (to layer III).

Two deepwater species can be considered separate from the above groups with regard to their vertical migration pattern. The first species (Gonatus fabricii) was abundant in the catches from all layers (II to V) at night and the majority (but not all) moved down to layer $V$ and possibly deeper during the daytime. Nesis (1977) noted the same pattern of vertical migration for this species, but Lu and Clarke (1975) considered that juveniles make reverse migrations. The other species (Leachia sp.) occurred during night and day in relatively large numbers, but they were concentrated mainly in layer $\mathrm{V}$ during the day and in the zone of maximum temperature (layer III) during the night. Roper and Young (1975) observed no pattern of vertical migration in Leachia sp. off Bermuda and considered that the juveniles concentrated in $50-100 \mathrm{~m}$ during both day and night.

No patterns of vertical movement could be inferred for Cranchia sabra, Ancistroteuthis lichtensteini, Helicocranchia pfefferi and Ornithoteuthis antillarum, because only a few specimens were caught.

The available data on diel distribution of cephalopods indicate that layers II, IV and V are the most important ones in terms of abundance and diversity of the squid species (Table 2). The first two layers are transitional, ecotonic zones. Layer II represents the transition from cold Shelf Water to warmer Slope Water, and layer IV represents the transition from warm Slope Water to colder North Atlantic Central Water. A peculiar feature was the much greater abundance and diversity of cephalopods in layers II and IV than in the intermediate layer III.

In general, the results of this study indicate that vertical migrations of various squid species depend mainly on the vertical structure of the water column, with depth being of lesser importance. Therefore, trawling at a standard depth (e.g. $100 \mathrm{~m}$ ) during the spring survey for juvenile I. illecebrosus, as described by Froerman (MS 1980), cannot give a valid estimate of the abundance of juveniles, because different sizegroups (i.e. 3,5 and $8 \mathrm{~cm} \mathrm{ML}$, in this paper) have different patterns of vertical distribution. In order to describe the cephalopod fauna in a certain region and to estimate their abundance, it is necessary first to divide the water column into zones which are characterized by some specific hydrographic features and then to make at least one trawl set in each zone during daylight and darkness but preferably at night. 


\section{Acknowledgements}

We thank E. N. Shevchenko and A. V. Remeslo of our Institute for their assistance during the 1983 survey, and V. V. Perov for his help in the preparation of this paper.

\section{References}

AMARATUNGA, T., and R. D. DURWARD. 1979. Standardization of data collection for the short-finned squid, Illex illecebrosus. ICNAF Sel. Papers, 5: 37-41.

DAWE, E. G., and P. C. BECK. 1985. Distribution and size of short-finned squid (Illex illecebrosus) larvae in the Northwest Atlantic from winter surveys in 1969, 1981 and 1982. J. Northw. Atl. Fish. Sci., 6: 43-55.

DAWE, E. G., P. C. BECK, and H. J. DREW. MS 1981. Distribution and biological characteristics of young short-finned squid (IIlex illecebrosus) in the Northwest Atlantic, February 20-March 11, 1981. NAFO SCR Doc., No. 23, Serial No. N302, $20 \mathrm{p}$.

DAWE, E. G., Y. M. FROERMAN, E. N. SHEVCHENKO, V. V. KHALYUKOV, and V. A. BOLOTOV. MS 1982. Distribution and size composition of juvenile short-finned squid (IIlex illecebrosus) in the Northwest Atlantic in relation to mechanisms of transport, February 4-April 30, 1982. NAFO SCR Doc., No. 25 (Rev.), Serial No. N513, 41 p.

FEDULOV, P. P., and Y. M. FROERMAN. MS 1980. Effect of abiotic factors on distribution of young shortfin squid, Illex illecebrosus (Lesueur, 1821). NAFO SCR Doc., No. 98, Serial No. N513, 22 p.

FROERMAN, Y. M. MS 1980. Biomass estimates of young I/lex illecebrosus (Lesueur, 1821) from a survey in Subareas 3 and 4 in March-April 1979. NAFO SCR Doc., No. 36,
Serial No. N067, $16 \mathrm{p}$.

FROERMAN, Y. M., P. P. FEDULOV, V. V. KHALYUKOV, E. N. SHEVCHENKO, and T. AMARATUNGA. MS 1981. Preliminary results of the R/V Atlant survey for short-finned squid, Illex illecebrosus, in Subarea 4 between 3 March and 4 May 1981. NAFO SCR Doc., No. 41, Serial No. N323, $13 p$.

HATANAKA, H., T. KAWAKAMI, E. FUJII, K. TAMAI, T. AMARATUNGA, J. YOUNG, D. CHAISSON, T. MCLANE, A. LANGE, L. PALMER, J. PREZIOSO, and M. SWEENEY. MS 1982. Aspects on the spawning season, distribution and migration of short-finned squid (Illex illecebrosus) in larval and juvenile stages in the Northwest Atlantic. NAFO SCR Doc., No. 32, Serial No. N520, 32 p.

HATANAKA, H., A. M. T. LANGE, and T. AMARATUNGA. 1985. Geographical and vertical distribution of shortfinned squid (Illex illecebrosus) larvae in the Northwest Atlantic. NAFO Sci. Coun. Studies, 9: 93-99.

LU, C. C., and M. R. CLARKE. 1975. Vertical distribution of cephalopods at $11^{\circ} \mathrm{N} 20^{\circ} \mathrm{W}$ in the North Atlantic. J. Mar. Biol. Assoc. U.K., 55: 369-389.

NESIS, K. N. 1977. Vertical distribution of pelagic cephalopods. Zh. Obshch. Biol., 38: 547-558 (in Russian).

1982. Concise key to the world ocean cephalopods. Lyogkaya i Pitc. Pr., Moscow, 360 p. (in Russian).

ROPER, C. F. E., and R. E. YOUNG. 1975. Vertical distribution of pelagic cephalopods. Smithson. Contrib. Zool., 209: $1-52$.

ROWELL, T. W., R. W. TRITES, and E. G. DAWE. 1985. Distribution of short-finned squid (Illex illecebrosus) larvae and juveniles in relation to the Gulf Stream frontal zone between Florida and Cape Hatteras. NAFO Sci. Coun. Studies, 9: 77-92.

VORONINA, N. M. 1984. Pelagic ecosystems of the southern oceans. Nauka Press, Moscow, 206 p. (in Russian). 